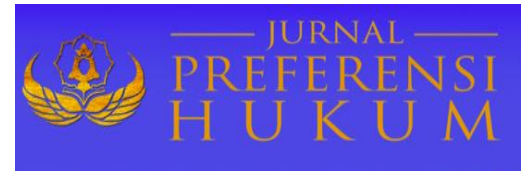

\title{
PERJANJIAN SEWA MENYEWA TANAH ADAT DI DESA SERANGAN DENPASAR SELATAN
}

\author{
I Putu Elvin Mahendra, I Made Suwitra, I Ketut Sukadana \\ Fakultas Hukum Universitas Warmadewa, Denpasar-Bali, Indonesia
}

\begin{abstract}
Abstrak
Kedudukan Desa Adat sebagai persekutuan hukum adat mempunyai wewenang dan kewajiban untuk menguasai, mengatur dan mengurus semua tanah milik Desa Adat yang berada dalam lingkungan wilayah Desa Adat tersebut sebagai hak ulayat. Negara mengakui otonomi asli desa adat tersebut, namun pemerintah belum menerbitkan surat penunjukkan desa adat yang berbadan hukum bisa memiliki hak atas tanah. Hal ini yang menyebabkan terjadinya ketidakpastian hukum apabila ingin melakukan usaha sewa menyewa tanah adat. Berdasarkan latar belakang ini, penelitian ini bertujuan untuk mengungkap bagaimana kewenangan Bendesa Adat dalam melakukan sewa menyewa tanah adat, dan bagaimana penerapan sanksi bagi pihak yang melakukan wanprestasi dalam perjanjian sewa menyewa tanah adat. Metode yang digunakan dalam penelitian ini adalah metode empiris, dengan mengkaji prosedur peraturan perundang-undangan yang berlaku dalam melakukan perjanjian sewa menyewa tanah adat serta menggunakan pendekatan masalah secara sosiologis hukum sosial yang berkaitan dengan norma-norma hukum baik dalam peraturan perundang-undangan maupun dalam awig-awig. Dalam PERDA Nomor 4 Tahun 2019 tentang Desa Adat di Bali mengatur mengenai tugas dan wewenang prajuru Desa Adat dalam memelihara perekonomian desa, sehingga berwewenang melakukan perbuatan hukum (perjanjian) khususnya perjanjian sewa menyewa tanah adat asalkan telah memenuhi persyaratan suatu perjanjian yang diatur dalam pasal $1320 \mathrm{KUH}$ Perdata. Sedangkan penerapan sanksi bagi pihak yang melakukan wanprestasi dalam perjanjian sewa menyewa tanah adat dilakukan berdasarkan kesepakatan Paruman desa dimana sanksinya tersebut dapat diselesaikan berdasarkan hukum positif di Indonesia, yaitu melalui proses peradilan. Oleh karena itu, Bandesa Adat memiliki peran yang sangat penting dalam urusan sewa menyewa tanah adat.
\end{abstract}

Kata Kunci: Perjanjian Sewa Menyewa; Tanah Adat

\begin{abstract}
The position of the Customary Village as a customary legal alliance has the authority and obligation to control, regulate and manage all the land belonging to the Customary Village within the Customary Village's territory as a customary right. The state recognizes the original autonomy of the customary village, but the government has not yet issued a letter designating customary villages which has legal status to have land rights. This causes legal uncertainty if a lease business for customary land is needed to conduct. Based on this background, this study aimed to reveal how the authority of the Bendesa Adat in leasing customary land, and how to apply sanctions for parties who default on the lease agreement for customary land. The method used in this study was an empirical method, by reviewing the statutory procedures that apply in making lease agreements for customary land and using a sociological problem approach to social law relating to legal norms both in legislation and in awig-awig. In PERDA Number 4 of 2019 concerning Customary Villages in Bali, it regulates the duties and authority of the Customary Villagers in maintaining the economy of the village, so they have the authority to carry out legal actions (agreements), especially customary land lease agreements provided that they meet the requirements of an agreement stipulated in article 1320 of the Indonesian Criminal Code Civil. Whereas the application of sanctions for parties who default in the lease agreement for customary land is carried out based on the agreement of the village Paruman where the sanctions can be resolved based on positive law in Indonesia, namely through the judicial process. Therefore, Bandesa Adat has a very important role in the matter of renting traditional land.
\end{abstract}

Keywords: Lease Agreement; Customary Land

\section{PENDAHULUAN}

Tanah adalah bagian yang tidak terpisahkan dari kehidupan, masyarakat dan komunitas adat (Besse Sugiswati, 2012; Kristiyanto, 2017). Orang-orang dan komunitas hukum umum dan kehidupan mereka mempunyai ketergantungan yang tinggi pada tanah, karena tanah adalah pijakan, tempat untuk mencari 
nafkah dan juga tempat di mana tempat peristirahatan terakhir setelah meninggal. Dalam ajaran Hindu dikatakan bahwa tanah adalah ibu pertiwi, oleh karena itu tanah dapat diartikan sebagai ibu dari semua makhluk hidup di alam semesta. Sebagai persekutuan hukum adat, desa adat didasarkan pada kesatuan teritorial yang berwenang dan berkewajiban menguasai tanah-tanah di desa adat di area desa adat (Zain \& Siddiq, 2015). Tanah itu berwujud tanah desa, tanah laba pura, tanah ayahan desa, tanah karang desa, dimana keberadaannya desa adat yang mengikatnya (Sudantra, 2018).

Hak sewa yaitu hak seseorang untuk menggunakan, mengolah, dan menikmati hasil dari kepemilikan orang lain dengan membayar sewa (Kartadimadja \& Tenges, 2020; Saputri, 2015). Properti yang bisa disewa meliputi tanah (sawah, kebun, sawah, kolam) yang membuat penyewa bisa mendapatkan keuntungan. Hak sewa tanah dapat berlaku dengan pembayaran sewa dibayar dimuka, atau bahkan pembayaran sewa balik dengan hasil tanah secara bertahap diperoleh (Dahen, 2006). Mengenai hak sewa, Pasal 44 UUPA menyatakan: Seseorang atau badan hukum memiliki hak untuk menyewakan tanah jika ia memiliki hak untuk menggunakan tanah yang dimiliki oleh orang lain untuk tujuan konstruksi dengan membayar uang sewa kepada pemilik. Pembayaran sewa dapat dilakukan satu kali atau pada waktu tertentu dan bahkan sebelum atau sesudah tanah digunakan jika interpretasi pasal 44 dan pasal 45 UUPA menyatakan bahwa negara tidak menyewakan tanah, karena negara bukan pemilik tanah, maka berdasarkan pasal 2 ayat 4 UUPA tentang masyarakat hukum adat (Desa Adat) yang disahkan oleh negara sebagai pelaksana (pengelola) atau ini berarti bahwa Desa Adat tidak memiliki hak untuk menyewa tanah karena Desa Adat bukan pemilik tanah (untuk sementara penunjukan Desa Adat sebagai suatu yang sah) entitas yang memiliki hak untuk memiliki properti) sesuai dengan Peraturan Pemerintah No. 38 tahun 1963 tentang penunjukan badan hukum. Batas badan hukum, menurut Subekti, adalah badan atau asosiasi yang dapat memiliki hak dan bertindak seperti seorang manusia, dan memiliki kekayaannya sendiri, dapat dituntut atau dituntut (Subekti, 1982). Dalam hubungan ini, Wirjono Prodjodikoro menyatakan bahwa badan hukum adalah suatu badan yang, selain sebagai individu, juga dianggap mampu bertindak dalam hukum dan juga memiliki hak, kewajiban dan hubungan hukum dengan orang atau badan lain (Ali, 1998).

Pemahaman desa adat sekilas sudah masuk kategori badan hukum dan juga lembaga sosial keagaman. Jika berhubungan dengan pengklasifikasian badan hukum, desa adat masuk kategori badan hukum publik, melingkupi warga desa dan wilayah yang nyata (Pribadiono, 2016). Dilihat dari tujuan sosial keagamana adalah tujuannya yang bisa dimohonkan menjadi badan hukum.

Syarat yang ditentukan sebagai badan hukum sudah dipenuhi bahkan lebih oleh desa adat (Rosyada, Warassih, \& Herawati, 2018). Adanya kelebihan dan kekhususan yang dimiliki desa adat membuatnya sangatlah tidak mungkin untuk bubar. Negara mengakui otonomi asli desa adat, namun pemerintah belum menerbitkan surat penunjukan desa adat yang berbadan hukum bisa memiliki hak atas tanah. Hal ini yang menyebabkan terjadinya ketidakpastian hukum apabila ingin melakukan usaha sewa menyewa tanah adat.

Berdasarkan latar belakang yang diuraikan di atas, penelitian ini dilakukan dengan tujuan mengungkap bagaimana kewenangan Bendesa Adat dalam melakukan sewa menyewa tanah adat, dan bagaimana penerapan sanksi bagi pihak yang melakukan wanprestasi dalam perjanjian sewa menyewa tanah adat.

\section{METODE PENELITIAN}

Penelitian ini didesain dengan menggunakan pendekatan hukum dengan aspek empiris. Pendekatan masalah dilakukan secara sosiologis hukum sosial, yaitu meliputi aturan perundang-undangan yang berlaku dengan pendekatan di masyarakat. Aspek hukum empiris ini bertujuan untuk mengungkapkan fenomena hukum dalam kehidupan nyata dalam masyarakat. Data yang sudah dikumpulkan dengan metode observasi dan wawancara. Kemudian data dianalisis dengan memilah-milah data yang dianggap penting dan dapat memberikan gambaran serta menginterpretasikan data-data yang telah terkumpul sehingga diperoleh gambaran secara umum dan menyeluruh tentang keadaan sebenarnya.

\section{HASIL DAN PEMBAHASAN}

\section{Kewenangan Bendesa Adat dalam Melakukan Sewa Menyewa Tanah Adat}


Prajuru Desa Adat Serangan diatur dalam Awig-awig Desa Pakraman Serangan Kecamatan Denpasar Selatan Kota Denpasar pada Palet 3 tentang Prajuru Pawos 10 Pepalihan Prajuru Desa seperti di bawah ini:

\section{Palet 3 indik Prajuru}

Pepalihan Prajuru Desa Pawos 10

Desa Pakraman serangan kaenterang/kapidabd antuk:

1. Paruman Desa

2. Sabha Desa (wali sowang-sowang banjar)

3. Kertha desa (prajuru lepas/panglingsir)

4. Prajuru luwire:

ha. Bendesa

na. Patajuh (parahyangan, pawongan lan palemahan)

ca. Penyarikan ra. Patengen ka. Kasinoman

da. Pangremba (para kelihan banjar)

5. Sajeroning tetimbang ngenterang desa kadegang sabha desa, maka miwah matutang utawi muputang wicara kadegang kertha desa, sane mawiwit prajuru lepas muah panglingsir desa, adiri maka panua saha angga muah panyarikan kaangkep antuk penyarikan desa

6. Rikala pengrestiti ring Kahyangan Desa, Bendesa miingsinggihang pamangku kahyangan tiga.

7. Munggwing pepalihan, ngadegang, swadarma muah swadikara saha wusan madeg prajuru banjar, sekaa teruna (maka anak anaking banjar) kapakusara ring banjar pakraman, utawi

Pawos 11 sekaa sowang-sowang manut pararem.

Pangadegan, swadarma lan swadikara prajuru, sabha saha kertha desa:

1. Bendesa Pakraman Serangan:

ha. Kaadegang malarapan pamilihan:

(1) Saking krama pangarep/muwed.

(2) Calon kasyagayang antuk sabha Desa (Saking prajuru lami utawi anyar): sane pawikan ring sastra agama, undagi plutuk desa, kalpa tatwa (adat, agama lan budaya Bali) saha tetap jumenek ring Desa Pakraman Serangan.

(3) Pikolih suara makehan sinanggeh Jero Gede Bendesa sane nglantur masitkayang pangwantu

(4) Panumaya ngayah selami 3 warsa sjawaning parindik tiyos tur kangkat malih 5 warsa salanturnyane.

(5) Matur upasaksi ring pura Kahyangan Tiga lan Paibon. na. Tetegenan/swadarma prajuru

2. Prade nglaksanayang swadarma, Bendesa kapialang kengin kawalinin antuk Panyarikannyane.

3. Ngwentenang utsaha, nincapang pamargin Tri Hia kArana, pamatut wicara lan siyosan punika, sanistane ngawarsa apisan bilih-bilih langungan ring ajeng paruman desa.

ca. Olih-olih Prajuru

(1) Cihna yasa swadarma riwusannyane

(2) Leluputan urunan (naur prabeya muah mamata matu)

4. Pangupeti/persen dana sane ngranjing ka desa utawi apah tigaan saking kekercen rikala wenten panauran ring kahyangan tiga.

ra. Wusan dados prajuru

(1) Sangkaning pinunas ngraga menawi sungkan-sungkanan magingsir genah ka dura desa

(2) Sangkaning panemaya

(3) Sangkanig kawusang, saantukan tan prasida ngesehin solah maprewerti

Berbicara tentang wewenang, Desa Adat sebagai komunitas hukum adat, yang membentuk unit teritorial, memiliki wewenang dan tugas untuk mengendalikan semua tanah milik desa Pakraman di dalam wilayah desa Desa Adat sebagai hak biasa, mengatur dan mengelola baik dalam bentuk tanah desa, tanah laba pura desa, tanah ayahan desa, desa desa karang.

Tanah-tanah tersebut merupakan tanah yang terikat pada Desa Adat. Tanah- tanah adat terikat pada Desa Adat karena tanah Desa Adat memiliki karakter umum, yaitu sebagai berikut (Perda Provinsi Bali, 2019). 
1. Masyarakat dan anggota-anggotanya dapat menggunakan tanah sebagai dasar bagi kehidupannya.

2. Orang bukan warga masyarakat hukum adat tidak dapat menggunakan hak itu, kecuali mendapatkan ijin dari masyarakat hukum adat yang bersangkutan.

3. Orang lain yang menggunakan hak itu harus membayar sesuatu kepada masyarakat hukum adat.

4. Masyarakat hukum adat bertanggung jawab terhadap segala perbuatan hukum yang terjadi di atas tanah tersebut.

5. Masyarakat hukum adat tidak boleh mengasingkan atau memindahtangankan kepada siapapun untuk selama-lamanya.

6. Masyarakat hukum adat dapat mencampuri terhadap penggunaan tanah yang telah digarap oleh anggotanya, agar dimanfaatkan secara wajar untuk memenuhi kebutuhan hidupnya

Berdasarkan sifat umum dari hukum adat, jelas ditetapkan orang yang bukan anggota masyarakat adat tidak dapat menggunakan hak atas tanah kecuali mereka mendapatkan izin dari komunitas common law, dan orang lain yang menggunakan hukum membayar sesuatu kepada komunitas hukum adat. Struktur desa Pakraman dalam organisasinya memiliki kepala desa adat bernama Bendesa Adat atau ada juga nama desa Kelihan Adat. Untuk desa Pakraman di Denpasar, mereka semua menggunakan istilah Bendesa. Diperkirakan bahwa istilah Bendesa berasal dari dua kata Bali, yaitu Banda, yang berarti tali, dan Desa, yang juga berarti penduduk desa atau penduduk desa. Sebagai Bendesa, kepala desa Adat dipandang sebagai simbol persatuan persatuan semua warga desa yang diharapkan mampu menyatukan perasaan keluarga warga desa, baik dalam keadaan bahagia atau sedih (Surpha, 2004).

Petajuh membantu bendesa dalam bertugas. Petajuh disebut dengan prajuru yang bertugas (Perda Provinsi Bali, 2019):

1. Melaksanakan awig-awig Desa Adat;

2. Mengatur penyelenggaraan upacara keagamaan di Desa Adat sesuai dengan sastra agama dan tradisi masing-masing;

3. Mengusahakan perdamaian dan penyelesaian sengketa adat;

4. Mewakili Desa Adat dalam bertindak untuk melakukan perbuatan hukum baik di dalam maupun di luar peradilan atas persetujuan paruman desa;

5. Mengurus dan mengatur pengelolaan harta kekayaan Desa Adat

6. Membina kerukunan umat beragama dalam wilayah Desa Adat.

\section{Penerapan Sanksi bagi Pihak yang Melakukan Wanprestasi dalam Perjanjian Sewa Menyewa Tanah Adat}

Desa Adat merupakan sebuah organisasi masyarakat hukum adat di Bali (kesatuan masyarakat hukum adat di Bali). Kepengurusannya dipimpin oleh prajuru desa pakraman, dalam hal ini diwakilkan oleh kepala desa yang disebut dengan Bendesa Adat. Segala bentuk pertanggungjawaban mengenai permasalahan yang menyangkut wilayah, harta kekayaan dan warga desa pakraman diserahkan kepada Bendesa Adat sebagai pemimpin Desa Adat. Oleh karena itu, Desa Adat merupakan sebuah lembaga atau organisasi yang dapat melakukan perbuatan-perbuatan hukum berkaitan dengan kegiatan yang dilakukan Desa Adat dalam rangka memelihara perekonomian desa maupun di bidang lainnya.

Desa Adat sering dikatakan sebagai subjek hukum (badan hukum) (Mulyanto, 2018; Ratmaningrum, Wairocana, \& Sumerthayasa, 2016). Dikatakan sebagai subjek hukum, karena subjek hukum itu sendiri terdiri atas manusia (orang) dan badan hukum. Oleh karena itu, Desa Adat merupakan sebuah lembaga tradisional (organisasi). Dengan demikian Desa Adat dapat disebut sebagai badan hukum. Apabila dilihat karakteristiknya, Desa Adat mempunyai ciri-ciri yang sama dengan badan hukum, yaitu merupakan suatu perkumpulan atau persekutuan, sama-sama mempunyai struktur (pengorganisasian) yang jelas (adanya prajuru dan pengurus Desa Adat), mempunyai tujuan tertentu dan mempunyai kekayaan sendiri (kekayaan yang dimaksud adalah tanah-tanah adat milik Desa Adat seperti tanah pekarangan desa, tanah ayahan desa, tanah druwe desa dan tanah pelaba pura). Dengan demikian Desa Adat dapat dikatakan sebagai bagian dari subjek hukum yaitu badan hukum yang diwakilkan oleh Bendesa Adat sebagai bentuk pertanggungjawaban lembaga (organisasi).

Desa Adat dapat melakukan perbuatan-perbuatan hukum yang berkaitan dengan Desa Adat apalagi untuk menunjang perekonomian desa demi keberlangsungan dari Desa Adat seperti melakukan perjanjian jual beli, sewa menyewa, utang piutang, dan yang lainnya. Dalam melakukan perbuatan 
hukum (perjanjian) khususnya perjanjian sewa menyewa tanah adat, desa pakraman dalam hal ini diwakili oleh Bendesa Adat harus memenuhi persyaratan dari sahnya suatu perjanjian dalam Pasal 1320 KUH Perdata.

Salah satu jenis perjanjian adalah perjanjian sewa menyewa yang dilakukan antara pengusaha dengan Desa Adat dalam hal ini diwakilkan oleh Bendesa Adat sebagai pemimpin atau prajuru Desa Adat karena mengingat salah satu tugas Bendesa Adat dapat dilihat pada Pasal 31 huruf (g) Peraturan Daerah Provinsi Bali Nomor 4 Tahun 2019 tentang Desa Adat adalah mewakili desa adat dalam bertindak untuk melakukan perbuatan hukum baik di dalam maupun di luar peradilan atas persetujuan paruman desa adat. Dan dari perjanjian sewa menyewa yang dilakukan antara pihak pengusaha dengan Desa Adat, mengakibatkan adanya hubungan hukum karena segala bentuk perjanjian adalah sah dan mengikat bagi mereka yang mengadakan perjanjian tersebut (Pasal 1338).

Berdasarkan wawancara dengan Bapak Made Sedana sebagai Bendesa Adat Desa Serangan pada hari Senin tanggal 12 Agustus 2019, dia mengatakan bahwa mengenai sanksi yang dapat diberikan kepada yang melanggar perjanjian khususnya perjanjian sewa menyewa tanah adat Bendesa, hal ini dapat dilakukan sesuai kesepakan paruman desa. Segala keputusan yang akan diambil harus diketahui dan disepakati oleh paruman desa yakni Desa Serangan. Namun mengenai penerapan sanksi yang diberikan biasanya dapat diselesaikan berdasarkan hukum positif di Indonesia, yaitu melalui proses peradilan. Alasan diselesaikan berdasarkan hukum positif adalah karena menurut beliau paruman desa yakni Desa Serangan telah memiliki kesepakatan dalam menyelesaikan setiap permasalahan dan perkara adat. Karena segala hal yang terjadi yang ada hubungannya dengan masalah adat, paruman desa memiliki tanggung jawab yang penuh dalam mengambil keputusan berdasarkan kesepakatan bersama. Selanjutnya hasil kesepakatan tersebut dapat dicatatkan pada perarem desa yakni Desa Serangan.

\section{SIMPULAN DAN SARAN}

\section{Simpulan}

Berdasarkan hasil analisis data yang telah dipaparkan sebelumnya, ada beberapa simpulan yang dapat dibuat, yaitu: pertama. kewenangan Bendesa Adat dalam melakukan sewa menyewa tanah adat yang merupakan pimpinan Desa Adat, dapat melakukan perbuatan hukum. Berkaitan dengan kegiatan yang dilakukan Desa Adat dalam rangka memelihara perekonomian desa, sehingga berwenang melakukan perbuatan hukum (perjanjian) khususnya perjanjian sewa menyewa tanah adat asalkan telah memenuhi persyaratan sahnya suatu perjanjian yang diatur dalam Pasal 1320 KUH Perdata. Kedua, penerapan sanksi bagi pihak yang melakukan wanprestasi dalam perjanjian sewa menyewa tanah adat diberikan kepada pihak yang melanggar perjanjian tersebut berdasarkan kesepakatan paruman desa. Sanksinya juga dapat diselesaikan berdasarkan hukum positif di Indonesia yaitu melalui proses peradilan.

\section{Saran}

Berdasarkan hasil penelitian ini, ada beberapa saran yang perlu disampaikan, yaitu: pertama, mekanisme penyewaan tanah Desa Adat perlu diatur dalam perarem desa untuk dapat menghindari hal-hal yang tidak diinginkan terjadi di kemudian hari, dan kedua, penyelesaian sengketa penyewaan tanah adat diupayakan dengan jalan mediasi, untuk dapat mempersingkat proses atau untuk mempercepat penyelesaiannya.

\section{DAFTAR PUSTAKA}

Ali, C. (1998). Badan Hukum (2nd ed.). Bandung: Alumni.

Besse Sugiswati. (2012). Perlindungan Hukum Terhadap Eksistensi Masyarakat Adat di Indonesia. Perspektif, XVII(1), 31-43. Retrieved from https://media.neliti.com/media/publications/156594ID-none.pdf

Dahen, L. D. (2006). Analisis Yuridis terhadap Hak-Hak atas Tanah yang Berada di atas Hak Pengelolaan Pelabuhan. Jurnal Ilmu Hukum, 3(1), 119-141. https://doi.org/10.1007/978-1-40205066-4_5

Kartadimadja, T. S., \& Tenges, J. E. (2020). Analisis Keabsahan Kepemilikan Tanah Oleh Orang Asing di Indonesia (Studi Kasus Nomor: 9/Pt.G/2018/PN.SKB). Jurnal PALAR (Pakuan Law Review), 06(01), 28-52. Retrieved from https://journal.unpak.ac.id/index.php/palar 
Kristiyanto, E. N. (2017). Kedudukan Kearifan Lokal dan Peranan Masyarakat dalam Penataan Ruang di Daerah. Rechts Vinding, 6(2), 159-177. Retrieved from https://media.neliti.com/media/publications/156594-ID-none.pdf

Mulyanto. (2018). Penguatan Masyarakat Hukum Adat dalam Undang-Undang Nomor 6 Tahun 2014 tentang Desa dari Perspectif Kajian Yuridis. Jurnal of Indonesian Adat Law (JIAL), 2(3), 74-104. Retrieved from https://www.researchgate.net/publication/340443009_PENGUATAN_MASYARAKAT_HUKU M_ADAT_DALAM_UNDANGUNDANG_NOMOR_6_TAHUN_2014_TENTANG_DESA_DARI_PERSPEKTIF_KAJIAN_ YURIDIS_Mulyanto

Perda Provinsi Bali. Peraturan Daerah Provinsi Bali Nomor 4 Tahun 2019 tentang Desa Adat di Bali. , (2019).

Pribadiono, A. (2016). Lembaga Desa Adat dalam Pembangunan Desa Menurut UU No. 6 Tahun 2014: Antara Kemandirian dan Subordinasi Pengaturan. Lex Jurnalica, 13(1), 10-22. Retrieved from https://media.neliti.com/media/publications/145649-ID-lembaga-desa-adat-dalampembangunan-desa.pdf

Ratmaningrum, J. W., Wairocana, I., \& Sumerthayasa, P. G. A. (2016). The Authority of Village Credit Union as the Subject of Liability Rights. Jurnal Ilmiah Prodi Magister Kenotariatan, 1(1), 188 195. Retrieved from https://media.neliti.com/media/publications/242134-none-88586b71.pdf

Rosyada, A., Warassih, E., \& Herawati, R. (2018). Perlindungan Konstitusional terhadap Kesatuan Masyarakat Hukum Adat dalam Mewujudkan Keadilan Sosial. Kanun Jurnal Ilmu Hukum, 20(1), 1-22. https://doi.org/10.24815/kanun.v20i1.10021

Saputri, A. D. (2015). Perjanjian Nominee dalam Kepemilikan Tanah Bagi Negara Asing yang Berkedudukan di Indonesia (Studi Putusan Pengadilan Tinggi Nomor: 12/PDT/2014/PT.DPS). Jurnal Repetorium, II(2), 96-104. Retrieved from https://media.neliti.com/media/publications/213115-perjanjian-nominee-dalam-kepemilikantan.pdf

Subekti. (1982). Aneka Perjanjian. Bandung: Alumni.

Sudantra, I. K. (2018). Implikasi Keputusan Menteri ATR/Kepala BPN Nomor 276/KEP-19 .2/X/2017 Terhadap Kedudukan Tanah Milik Desa Pakraman. Jurnal Magister Hukum Udayana, 7(4), 546564. https://doi.org/10.24843/JMHU.2018.v07.i04. p01

Surpha, I. W. (2004). Eksistensi Desa Adat dan Desa Dinas di Bali. Denpasar: Pustaka Bali Post.

Zain, M. A., \& Siddiq, A. (2015). Pengakuan atas Kedudukan dan Keberadaan Masyarakat Hukum Adat (MHA) Pasca Dibentuknya Undang-Undang Nomor 6 Tahun 2014 Tentang Desa. Jurnal Penelitian Hukum, 2(2), 63-76. Retrieved from file:///D:/RENCANA USULAN RISET (SUR) NELWAN 2019/122554-ID-pengakuan-atas-kedudukan-dan-keberadaan.pdf 